\title{
DESAIN TAPAK PERKEMAHAN KONSERVASI DI LABORATORIUM LAPANGAN KONSERVASI SUMBERDAYA HUTAN DAN EKOWISATA HUTAN PENDIDIKAN UNHAS
}

\author{
Field Design of Conservation Camp In The Field Laboratory Of Forest Resources Conservation And Ecotourism \\ Unhas Educational Forest
}

\author{
Amran Achmad ${ }^{1 凶}$, Putu Oka Ngakan ${ }^{1}$, Roland Barkey $^{1}$, Usman Arsyad ${ }^{1}$, Nida' Sari Achmad ${ }^{2}$ \\ 1 Universitas Hasanuddin, Jl. Perintis Kemerdekaan km 10, Makassar. TIp. 0411-585917 Fax 0411-589592 \\ 2 Eco-Conservation Konsultan,. Perdos Unhas Tamalanrea Blok GB.45, Makassar \\ ${ }^{\otimes}$ corresponding author: amhutan@yahoo.com
}

\begin{abstract}
This study aims to design a conservation campsite that comfortable and attractive, which is also as a place of education for the conservation of natural resources and their ecosystems. This research was conducted at the Field Laboratory of Forest Resources Conservation and Ecotourism Unhas Educational Forest. Field data collection of altititude was done by using a systemic sampling method on 358 sample points, with the distance between each sample point was $10 \mathrm{~m}$. Data was processed by Digital Elevetaion Model (DEM). The results are then used to create a map of the slopes and contours. The location of tents and other camp facilities, set based on the direction of the view that shows open views, elevation position with height difference based on the height of the tent, the shape of the tent (dom and platoon), distance between tents, slope classes, other campground facilities, such as toilets, public kitchens , cultural stage, as well as activities in conservation camps such as games, campfires, and others. The results showed that conservation camps at the Field Laboratory of Forest Resources Conservation and Ecotourism, were divided into four camp blocks. Block I accommodates eight tents that placed in the three rows, eight tents in block II in two rows, and 23 tents in block III in a position of four rows. For block IV prepared for tent tents, with a capacity of four tents in a two-row position. The campground facilities are in the form of cultural stage, resting area, musallah, management house and public kitchen, toilet, gazebo, and sports field. The design of field learning related to conservation involves three themes, namely (a) the introduction of biological natural resources and their ecosystems, (b) the introduction of ecology, and (c) conservation area management.
\end{abstract}

Key words: Field Design, Campground, Conservation Education.

\section{A. PENDAhULUAN}

Hutan pendidikan Unhas, memiliki potensi biofisik yang dikelola untuk tujuan pendidikan, penelitian dan pengabdian masyarakat. Bentuk pemanfaatan yang mencakup ketiga fungsi di atas, adalah memanfaatkan sumberdaya hutan pendidikan untuk tujuan wisata tetapi sekaligus melakukan pelestarian terhadap sumber daya tersebut beserta ekosistemnya (Achmad dkk (2015). Salah satu bentuk pengelolaan dan pemanfaatan hutan yang paling logis dan layak untuk dilakukan tanpa merusak ekosistem yang berada di dalamnya adalah pemanfaatan hutan dari aspek rekreatif, estetik, dan edukatif (Douglas 1982; Achmad dkk., 2012a)

Pemanfaatan hutan dari aspek rekreatif, estetik, dan edukatif dapat diwujudkan melalui berbagai macam cara, dan salah satu diantaranya adalah dengan kegiatan kemah konservasi (Robin, 2003; Gogo, 2014). Kemah konservasi adalah kegiatan pembelajaran konservasi yang dilakukan di alam terbuka dengan alat bantu kemah sebagai tempat tidur maupun belajar (Knudson, 1983; Sulaeman, 1983). Kemah konservasi umumnya dilakukan pada suatu areal yang disebut sebagai areal perkemahan atau bumi perkemahan (Douglas 1982; Knudson, 1983; Sulaeman 1983; Robin 2003) Areal perkemahan merupakan areal yang dibutuhkan untuk mendirikan tenda, bengkel kerja, serta sarana dan prasarana dalam menunjang terlaksananya kegiatan kemah konservasi (Douglas, 1982; Direktorat Pemanfaatan Jasa Lingkungan dan Wisata Alam, 2009).

Laboratorium Lapangan Konservasi sumberdaya Hutan dan Ekowisata, merupakan salah satu laboratorium lapangan di Hutan Pendidikan Unhas yang telah melakukan berbagai penelitian yang berkaitan dengan konservasi sumberdaya hayati dengan tujuan pemanfaatan non konsumtif, seperti pemanfaatan untuk ekowisata. Achmad dkk., (2012a) telah melakukan penelitian pengebangan ekowisata di laboratorium lapangan tersebut, dimana salah satu potensi yang cukup 
menarik adalah adanya areal yang berpotensi untuk lokasi areal perkemahan.

Pemilihan lokasi kemah konservasi merupakan langkah awal dari kegiatan perancangan kemah konservasi. (Direktorat Pemanfaatan Jasa Lingkungan dan Wisata Alam. 2009). Achmad dkk., (2012b) menginformasikan bahwa lokasi kegiatan areal perkemahan di Laboratorium Lapangan Konserasi Sumberdaya Hutan dan Ekowisata, memiliki landskap yang cukup datar dan dipandang layak untuk dipilih sebagai lokasi kegiatan kemah konservasi. Aspek biofisik di sekitarnya cukup mendukung dalam memenuhi hasrat petualang bagi para pengunjung yang akan mengunjungi lokasi ini karena memiliki kekayaan sumberdaya flora fauna, topografi, pemandangan alam dan air terjun. Bahkan beberapa diantara flora faunanya merupakan spesies langka dan endemik sulawesi sehingga berpotensi untuk dimanfaatkan untuk kegiatan pendidikan melalui model kemah konservasi.

Dalam kegiatan kemah konservasi, pekemah tidak hanya menikmati pemandangan alam, tetapi mereka harus diarahkan untuk memahami tentang sumberdaya hayati beserta ekosistemnya melalui pendidikan konservasi secara langsung di alam terbuka di sekitar lokasi perkemahan (Ichwan, M. 2009). Fandeli dan Muhammad, 2009); Setiono, 2011) menjelaskan bahwa pendidikan konservasi bertujuan untuk menumbuhkan sikap dan cara berpikir yang positif terhadap sumberdaya alam dan ekosistem beserta upaya konservasinya. Dengan demikian orang akan semakin bijaksana dalam mengelola (termasuk memanfaatkan) sumber daya alam, sehingga dalam melakukan kegiatan sehari-hari akan selalu berwawasan lingkungan. Pendidikan konservasi tidak mesti diartikan sesuatu cabang dari ilmu pendidikan. Tujuan utamanya adalah pendekatan dan penginterpretasian "alam lingkungan hidup". Akan tetapi pendidikan konservasi bukan hanya sekedar memberi pengetahuan kepada masyarakat tentang lingkungan hidupnya, tetapi lebih dari itu menunjukkan pada mereka "tempat sebenarnya" dimana mereka tinggal dan hubungan dengan sekelilingnya sehingga mereka tahu cara berperilaku yang benar/baik.

Tujuan penelitian ini adalah

1) Membuat desain perkemahan konservasi yang nyaman dan menarik, serta merupakan tempat pendidikan konservasi sumberdaya alam hayati beserta ekosistemnya.

2) Menyusun rancangan kegiatan pendidikan lapangan tentang konservasi sumberdaya hayati dan ekosistemnya yang merupakan bagian dari pelaksanaan kegiatan perkemahan konservasi.

\section{B. METODE PENELITIAN}

\section{Lokasi dan Waktu Penelitian.}

Kegiatan penelitian desain tapak perkemahan konservasi, berlokasi di Laboratorium Lapangan Konservasi Sumberdaya Hutan dan Ekowisata Hutan Pendidikan Unhas Kabupaten Maros. Luas areal perkemahan yang telah teridentifikasi, kurang lebih 2 ha. Areal perkemahan konservasi yang terletak di puncak Wirawan, selain mempunyai potensi pemandangan yang indah dari dua sisi, juga mempunyai potensi berupa hutan tanaman pinus dan satwa liar burung, reptil dan kera yang dapat dimanfaatkan selain untuk kegiatan ekowisata, juga untuk pendidikan konservasi. Dengan demikian, pengunjung yang menginap di lokasi tersebut dapat merasakan langsung manfaat dan fungsi dari konservasi sumberdaya alam hayati dan ekosistemnya.

\section{Variabel Yang Dikumpulkan}

Variabel desain tapak areal perkemahan untuk pengembangan ekowisata dan pendidikan konservasi. Untuk memudahkan kegiatan pengumpulan dan pemrosesan data, data diklasifikasi menjadi tiga bentuk, yaitu: point (titik koordinat), line (garis jalur maupun transek jalan), dan polygon (areal).

a. Data point adalah berupa data koordiat pada titik-titik tertentu yang mempunyai perdeaan tinggi di atas permukaan laut di dalam areal perkemahan. Data ini digunakan untuk membuat peta kontur dan kelerengan dengan skala detail sebagai dasar dalam membuat desain tapak perkemahan

b. Data line adalah berupa data dalam bentuk garis untuk menggambarkan posisi jalan setapak yang ada di dalam dan sekitar areal perkemahan

c. Data polygon adalah berupa data batas luar dari areal perkemahan.

\section{Cara Pengumpulan dan Pengolahan Data}

\section{Pengumpulan Data Untuk Desain Areal Perkemahan}

1) Batas luar perkemahan diukur dengan menggunakan GPS, yakni dengan melakukan tracking mengikuti batas luar. Hasil data tracking akan diolah dengan software GIS sehingga bisa dikonversi menjadi data polygon atau keruangan.

2) Alur jalan setapak di dalam dan sekitar areal perkemahan, juga diukur dengan menggunakan GPS melalui tracking sepanjang alur jalan. Hasil data tracking akan diolah dengan software GIS sehingga bisa dikonversi menjadi data line yang menggambarkan alur jalan yang telah diukur.

3) Titik-titik yang akan digunakan sebagai base line pembuatan peta kontur tingkat detail, diukur koordinatnya dan posisi ketinggian dari permukaan laut. Titik diambil setiap jarak $10 \mathrm{~m}$ dengan sistematik. Untuk memudahkan pekerjaan di lapangan, titik 
sampling tersebut terlebih dahulu ditetapkan di atas peta kerja yang mencakup areal yang berpotensi sebagai lokasi perkemahan dan sekitarnya.

4) Titik pertama ditentukan posisi koordianatnya dengan GPS dengan berdasarkan koordinat peta. Selanjutnya diukur titik tingginya dengan menggunakan GPS.

5) Untuk titik selanjutnya, dilakukan pengukuran beda tinggi dengan berbasis titik pertama, dengan menggunakan abney level.

6) Hasil pengukuran beda tinggi pada setiap titik, digunakan untuk menghitung tinggi dari permukaan laut dari setiap titik tersebut dengan menggunakan rumus :

7) Koordinat dan nilai ketinggian dari setiap titik yang diukur, diolah dengan metode GIS dengan menggunakan teknik Digital Elevation Model (DEM) guna menghasilkan peta surface lapangan, untuk kemudian digunakan dalam menurunkan peta kontur dan peta kelas kelerengan.

8) Verifikasi lapangan untuk mencocokan apakah model topografi yang dihasilkan dari digital elevation model sudah sesuai dengan keadaan lapangan.

9) Melakukan justifikasi jika ada ketidak sesuaian di lapangan untuk menghasilkan model terakhir yang sesuai dengan keadaan lapangan yang sebenarnya.

2. Pengumpulan Data Untuk Rancangan Kegiatan Pendidikan Lapangan Konservasi Sumberdaya Hayati dan Ekosistemnya.

1) Pengumpulan data flora fauna, budaya masyarakat dan gejalah alam seperti air terjun, dilakukan dengan metode sekunder. Data ini dikumpulkan dari hasil-hasil penelitian yang telah dilakukan sebelumnya, untuk kemudian dipakai dalam menyusun rancangan kegiatan pendidikan lapangan, serta untuk mendeskripsikan secara detail objek flora fauna, budaya masyarakat dan gejalah alam yang digunakan dalam pendidikan lapangan tersebut dengan metode game. Penentuan jenis flora dan fauna penting yang digunakan dalam pendidikan lapangan ini, ditetapkan berdasarkan nilai kepentingannya dalam ekositem, seperti manfaat untuk obat-obatan, pakan satwa, berstatus endemik atau dilindungi, sebagai bahan makanan, dan lain-lain.

2) Penentuan batas jangkauan eksploarsi ditetapkan berdasarkan pertimbangan kemudahan untuk dijangkau oleh peserta perkemahan.

\section{Desain Areal Perkemahan}

Desain adalah proses pemikiran dari suatu ide ke arah bentuk yang nyata (Nurisyah dan Pramukanto, 1995; Dardak, 2006) Berdasarkan peta topografi dan kelerangan yang dihasilkan dengan metode GIS, kemudian dibuat rancangan tapak perkemahan dengan mempertimbangkan (1) Arah view yang memperlihatkan pemandangan terbuka, (2) Posisi ketinggian dengan selisih ketinggian berdasarkan tinggi tenda/kemah, (3) Tipe tenda untuk kapasitas 3 sampai 4 orang dan tenda besar, (4) Jarak antar tenda, (5) Kelas kelerengan, (6) Fasilitas areal perkemahan lainnya, seperti toilet, dapur umum, panggung budaya, dan (7) Kegiatan atau aktifitas dalam kemah konservasi seperti games, api unggun, dan lain-lain.

\section{HASIL}

\section{Varisasi Ketinggian Topografi}

Berdasarkan hasil perhitungan posisi ketinggian dari 358 titik sampel, diketahui bahwa variasi ketinggian dari areal penelitian bervariasi dari $527 \mathrm{~m}$ dpl sampai 589,6 m dpl. Hasil analisis menunjukkan bahwa lokasi penelitian di dominasi oleh topografi dengan ketinggian antara $543 \mathrm{~m}$ dpl sampai $558 \mathrm{~m}$ dpl. Variasi ketinggian pada interval ini, mempunyai pengulangan lokasi dari 10 titik sampai 29 titik. Hal ini menunjukkan bahwa pada areal penelitian, paling tidak ditemukan beberapa lokasi yang berpotensi mempunyai potensi topografi relatif datar dengan perbedaan tinggi antara satu sampai 15 meter.

Titik ketinggian dengan nilai terendah (527 m dpl) hanya ditemukan pada dua titik. Di lapangan, kedua titik ini berhadapan dengan titik yang tepat berada di Puncak Wirawan, dengan perbedaan ketinggian mencapai $17 \mathrm{~m}$. Hal ini menyebabkan bagian sepanjang 20 meter dimana kedua titik terendah ini berada, membentuk jurang yang dalam yang menghasilkan tempat terbuka, sehingga menghasilkan pemandangan ke arah Selatan. Latar belakang pemandangan dari tempat ini adalah Bulu Lasoa di bagian bawah, serta deretan Gunung Makkarua, Bulu Lompoa dan Mallali Alo di bagian belakang (Achmad, dkk. 2012).

Titik tertinggi (589 m dpl) ditemukan pada ujung Utara Barat pada Gunung Pareppekang. Perbedaan ketinggian titik ini dengan titik di sekitarnya rata-rata hanya mencapai kurang lebih 1 meter pada setiap jarak $10 \mathrm{~m}$, sehingga menciptakan kelerengan yang tidak terjal seperti yang terjadi di Puncak Wirawan.

\section{Deliniasi Batas Areal Perkemahan}

Berdasarkan pengukuran lapangan pada areal yang terbuka dan dipandang layak untuk dijadikan sebagai lokasi perkemahan, ditetapkan areal untuk pengembangan kemah konservasi seperti diperlihatkan pada Gambar 1. Berdasakan hasil analisis overlay antara lokasi pengukuran titik sampel dengan batas areal kemah konservasi, diketahui bahwa areal untuk pengembangan kemah konservasi hanya mencapai $52,5 \%$ atau 1,89 ha dari total areal yang diukur dan dianalisis titik tingginya, yakni 3,6 ha. Hasil analisis ini juga memperlihatkan bahwa ketinggian di dalam areal kemah konservasi bervariasi dari $538 \mathrm{~m}$ dpl sampai $578 \mathrm{~m}$ dpl. (Gambar 2) 


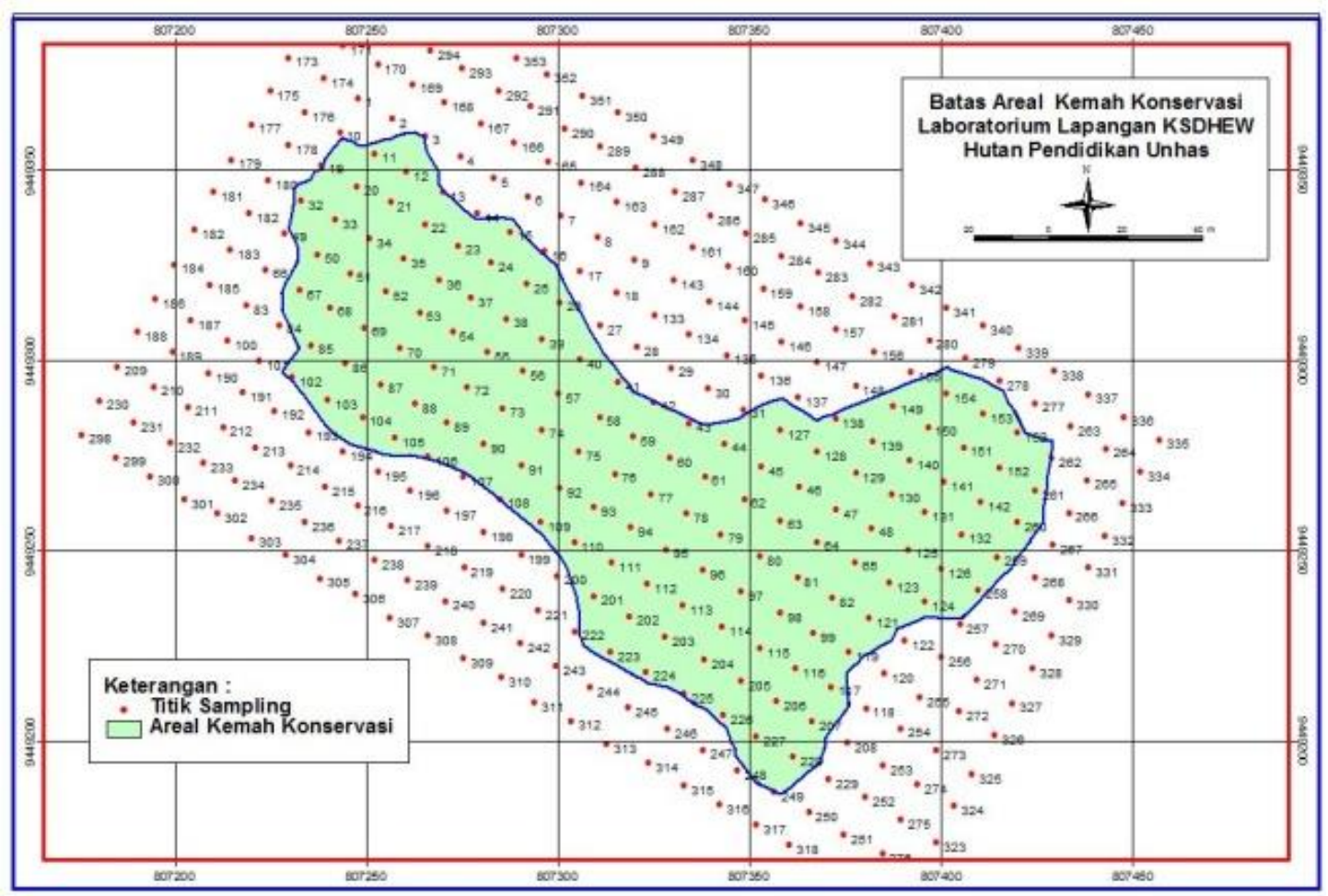

Gambar 1. Peta batas areal kemah konservasi terpilih.

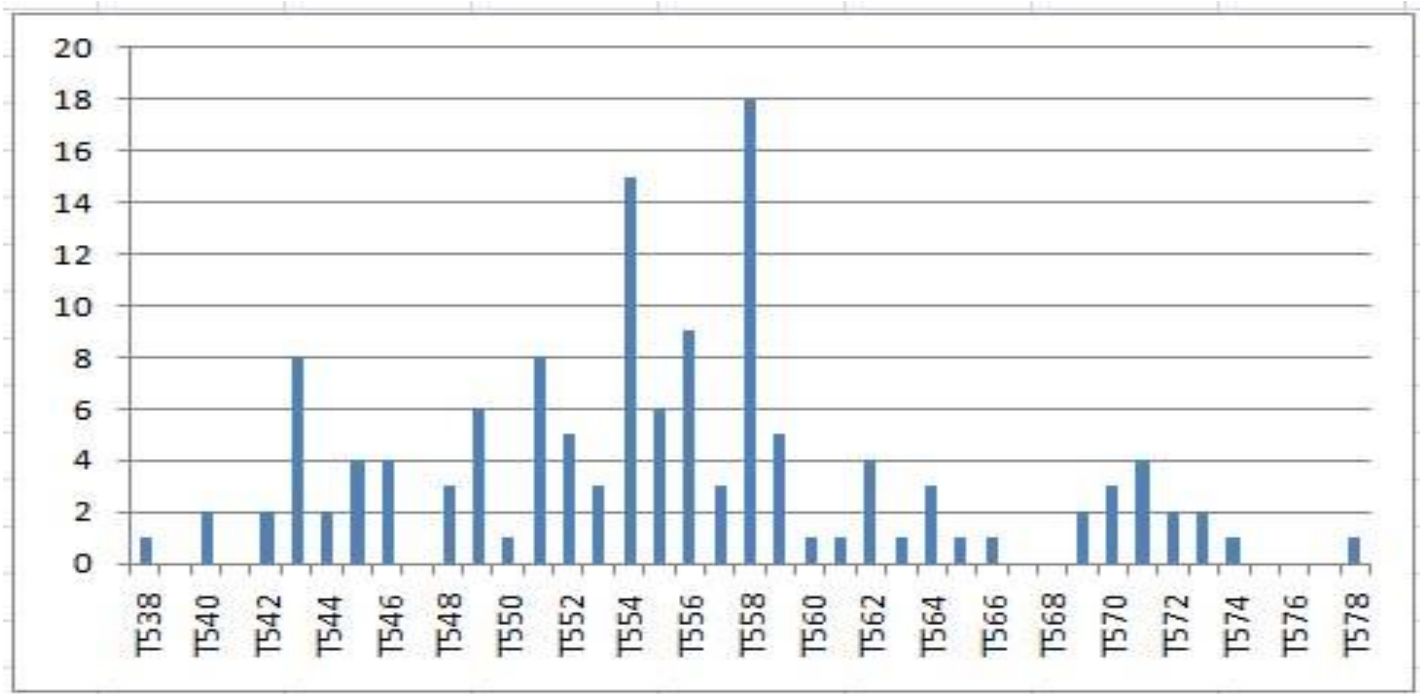

Gambar 2. Distribusi sebaran ketinggian di dalam areal kemah konservasi

Gambar 2 memperlihatkan bahwa topografi dengan ketinggian antara $543 \mathrm{~m}$ dpl sampai $558 \mathrm{~m}$ dpl yang dominan sebarannya pada areal penelitian, sebagian besar berada di dalam areal kemah konservasi yang terpilih, namun jumlah titik-titik yang mewakili lokasi-lakasi tersebut berkurang menjadi 8 titik sampai 18 titik. Dari Gambar 4 juga diketahui bahwa pada areal kemah konservasi mempunyai titik ketinggian terendah berada pada $538 \mathrm{~m} \mathrm{dpl}$, sedangkan posisi ketinggian tertinggi berada pada $578 \mathrm{~m}$ dpl, dengan selisih kedua ketinggian tersebut sebesar $40 \mathrm{~m}$ Hal ini menunjukkan bahwa di dalam areal kemah konservasi, ada titik-titik dimana kita bisa melihat pemandangan terbuka, karena tinggi tajuk maksimum pohon-pohon di sekitar kema konservasi hanya mencapai kurang lebih $25 \mathrm{~m}$.

Gambar 2 juga menunjukkan bahwa paling tidak ditemukan lima lokasi yang berpotensi mempunyai topografi relatif datar pada lima kelas ketinggian yang berbeda. Hal ini memungkinkan desain peletakkan kemah dan fasilitas penunjang perkemahan, tidak monoton atau 
mempunyai variasi berdasarkan perbedaan ketinggian. Hasil analisis juga memperlihatkan bahwa titik ketinggian dari $527 \mathrm{~m}$ dpl sampai titik ketinggian $537 \mathrm{~m}$ dpl, serta titik ketinggian dari $579 \mathrm{~m} \mathrm{dpl} \mathrm{sampai} .589 \mathrm{~m} \mathrm{dpl}$, tidak ada dalam areal kemah konservasi. Hal ini menunjukkan bahwa areal kemah konservasi yang terpilih cukup datar atau tidak mempunyai titik ketinggian yang ekstrim, sehingga dalam pengembangannya tidak banyak mengganggu kondisi topografi yang ekstrim. Dengan demikian, dampak pengembangan kemah konservasi tersebut terhadap lingkungan sekitarnya, diduga akan relatif kecil. Hasil pengukuran titik ketinggian di lokasi penelitian, kemudian digunakan untuk membuat peta permukaan (surface) dengan tehnik Triangulated Irregular Network (TIN) atau Digital Elevation Model (DEM) yang berfungsi sebagai sumber data untuk memproduksi peta topografi dan peta kelerengan

\section{Analisis Topografi}

Berdasarkan data surface kemudian diturunkan peta kontur detail dengan jarak kontur $1 \mathrm{~m}$, seperti diperlihatkan pada Gambar 3. Gambar tersebut memperlihatkan garis kontur dengan kerapatan yang lebar pada empat lokasi, kerapatan sedang pada tiga lokasi, dan sisahnya dengan kerapatan kontur yang padat. Varisi topografi seperti diperlihatkan pada gambar tersebut di atas, akan mempengaruhi penyeberan penempatan tenda dan fasilitas perkemahan di dalam areal perkemahan yang di desain.

\section{Kelas Kelerengan}

Selain peta kontur, peta kelerengan juga dirueunkan dari data dari data surface. Berdasarkan peta lereng, diketahui bahwa areal penelitian mempunyai empat kelas kelerengan, yakni datar, landai, bergelombang dan agak curam. Kelas kelerengan di dalam areal pengembangan kema konservasi, didominasi oleh kelas kelerengan datar sampai bergelombang. Luas areal masing-masing kelas kelerengan di dalam dan di luar areal pengembangan kema konservasi,disajikan pada Tabel 1.

\section{Desain Tapak.}

Seperti dijelaskan sebelumnya, bahwa lokasi areal kemah konservasi mempunyai dua titik pandang (view) yang berbeda, sehingga posisi fasilitas perkemahan, seperti lokasi tenda dan fasilitas pendukung lainnya perlu dirancang dengan baik, sehingga lokasi perkemahan tidak hanya akan menjadi nyaman dan menarik, tetapi pekemah sekaligus dapat menikmati pemadangan yang indah meskipun hanya duduk di dalam atau di depan kemah mereka. Dua arah view yang dimaksud adalah ke arah Timur dengan latar belakang pemandangan Malakka, sedangkan ke arah Selatan dengan latar belakang pemandangan Gunung Bulu Lasoa di bagian bawah, serta deretan Gunung Makkarua, Bulu Lompoa dan Mallali Alo di bagian belakang, Skema kedua arah view di lokasi perkemahan konservasi, diperlihatkan pada Gambar 4.

\section{1. 'Fasilitas Tenda Camping}

Berdasarkan Gambar 4, kemudian dibuat sketsa peletakkan lokasi fasilitas perkemahan dengan mempertimbangkan peta kelas kelerengan, tutupan vegetasi yang ada di sekitarnya, sebaran pohon yang ada dalam lokasi perkemahan, serta perbedaan ketinggian dan luas setiap tapak pada kelas kelerengan tertentu. Dari hasil pertimbangan variabel tersebut di atas, kemudian ditetapkan tiga blok lokasi untuk tendah dom dengan kapasitas 2 sampai 6 orang, serta satu blok untuk tenda platon yang berkapasitas 10 sampai 20 orang. Jumlah tendah dom yang dapat di pasang pada setiap blok saling berbeda, sedangkan untuk blok tenda platon maksimum sampai empat tenda.

Berdasarkan hasil analisis luas areal kebutuhan setiap tenda, jarak antar tenda, perbedaan tinggi antar tenda, serta keterbukaan view setiap tenda, maka ditetapkan sebanyak sepuluh tenda yang dapat dipasang pada blok I dengan posisi tiga baris, sembilan tenda pada blok II dengan posisi dua baris, serta 23 tenda pada blok III dengan posisi sebanyak empat baris. Untuk blok IV yang disiapkan untuk tenda platon, hanya berkapasitas empat tenda dengan posisi dua baris.

Tabel 1. Hasil perhitungan luas masing-, asing kelas kelerengan di lokasi penelitian

\begin{tabular}{|c|c|c|c|c|c|}
\hline \multirow[t]{2}{*}{ No. } & \multirow{2}{*}{$\begin{array}{l}\text { Kelas Kele- } \\
\text { rengan (\%) }\end{array}$} & \multirow{2}{*}{$\begin{array}{c}\text { Kelas } \\
\text { Topografi } \\
\end{array}$} & \multicolumn{2}{|c|}{ Luas Areal (ha) } & \multirow{2}{*}{$\begin{array}{l}\text { Total Luas } \\
\text { (ha) }\end{array}$} \\
\hline & & & Perkemahan & Lainnya & \\
\hline 1. & $0-8$ & Datar & 0,63 & 0,37 & 1,00 \\
\hline 2. & $8-15$ & Landai & 0,61 & 0,39 & 1,00 \\
\hline 3. & $15-25$ & Agak Terjal & 0,47 & 0,00 & 0,47 \\
\hline 4. & $25-40$ & Terjal & 0,18 & 0,95 & 1,13 \\
\hline & & Total & 1,89 & 1,71 & 3,6 \\
\hline
\end{tabular}




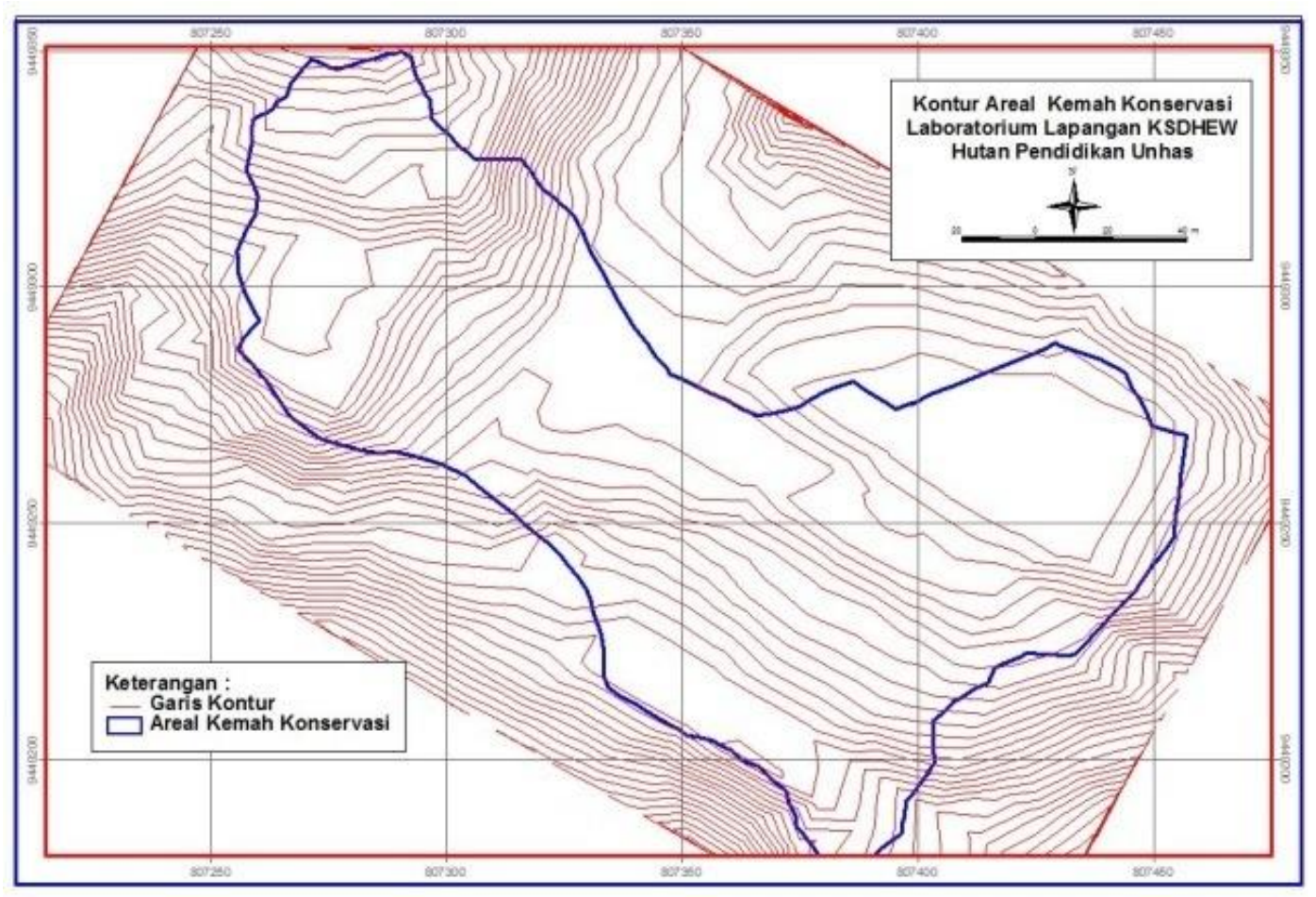

Gambar 3. Peta topografi areal kemah konservasi

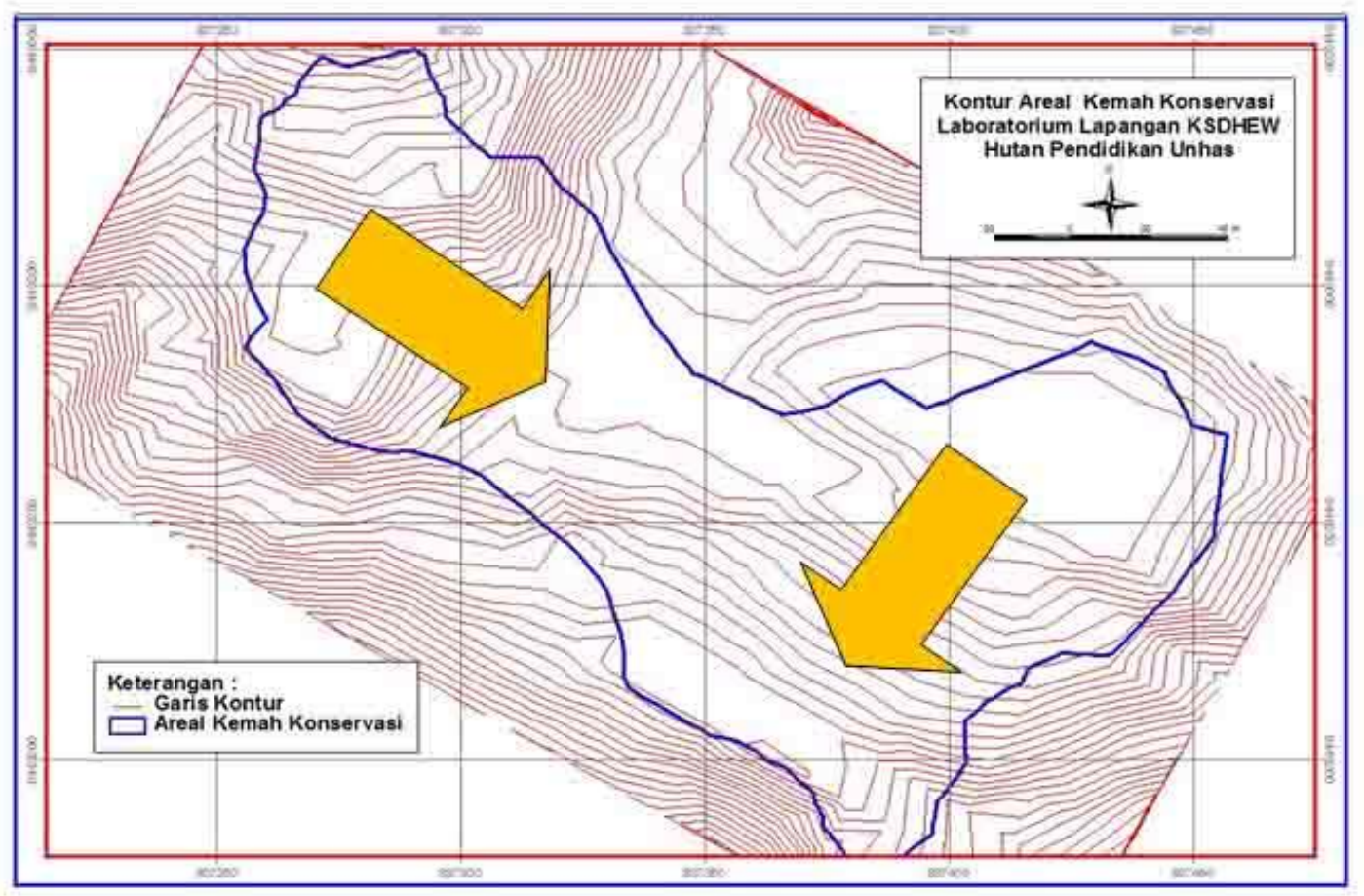

Gambar 4. Dua arah view pada lokasi kemah konservasi 


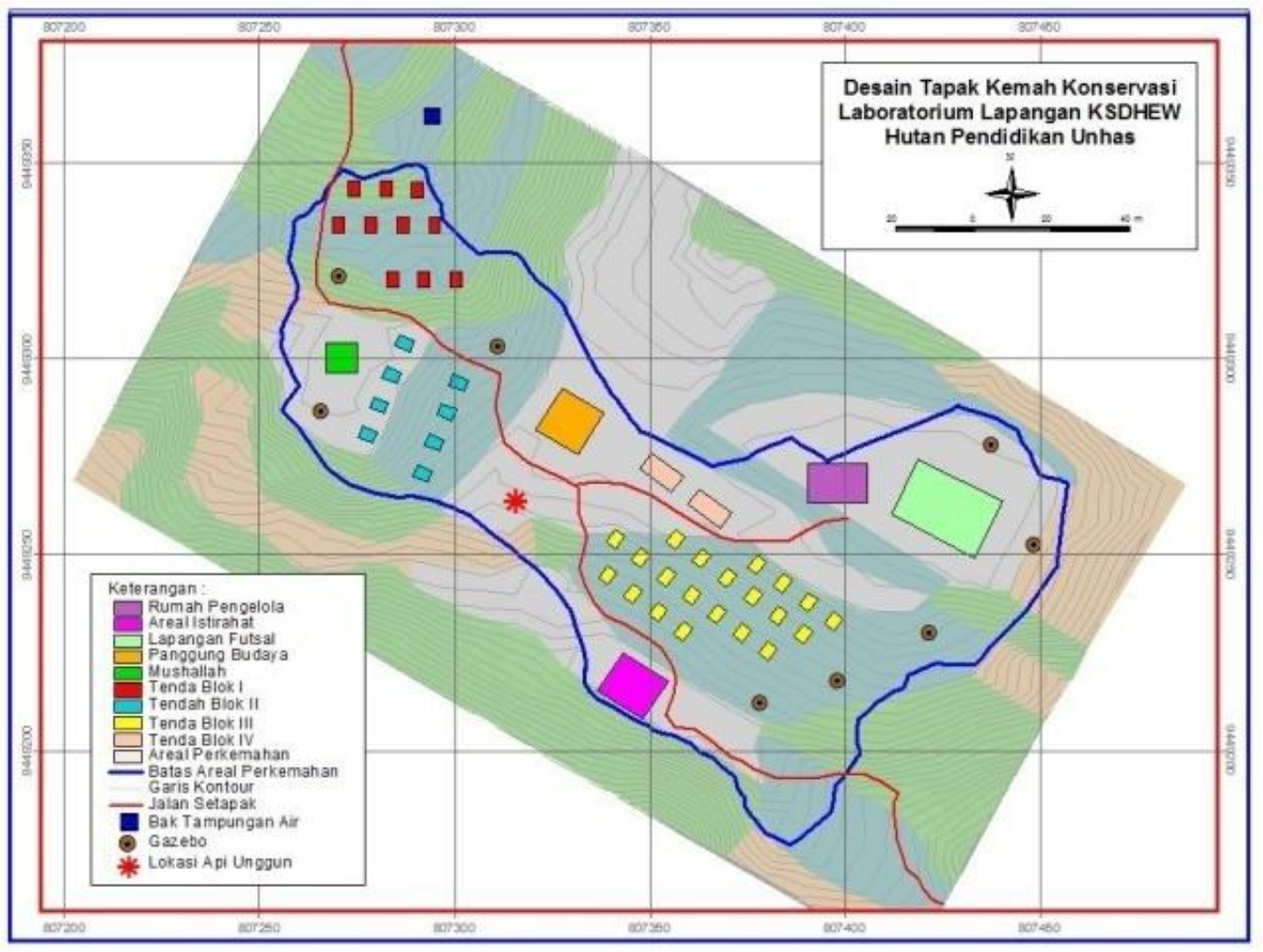

Gambar 5. Peta desain kemah konservasi

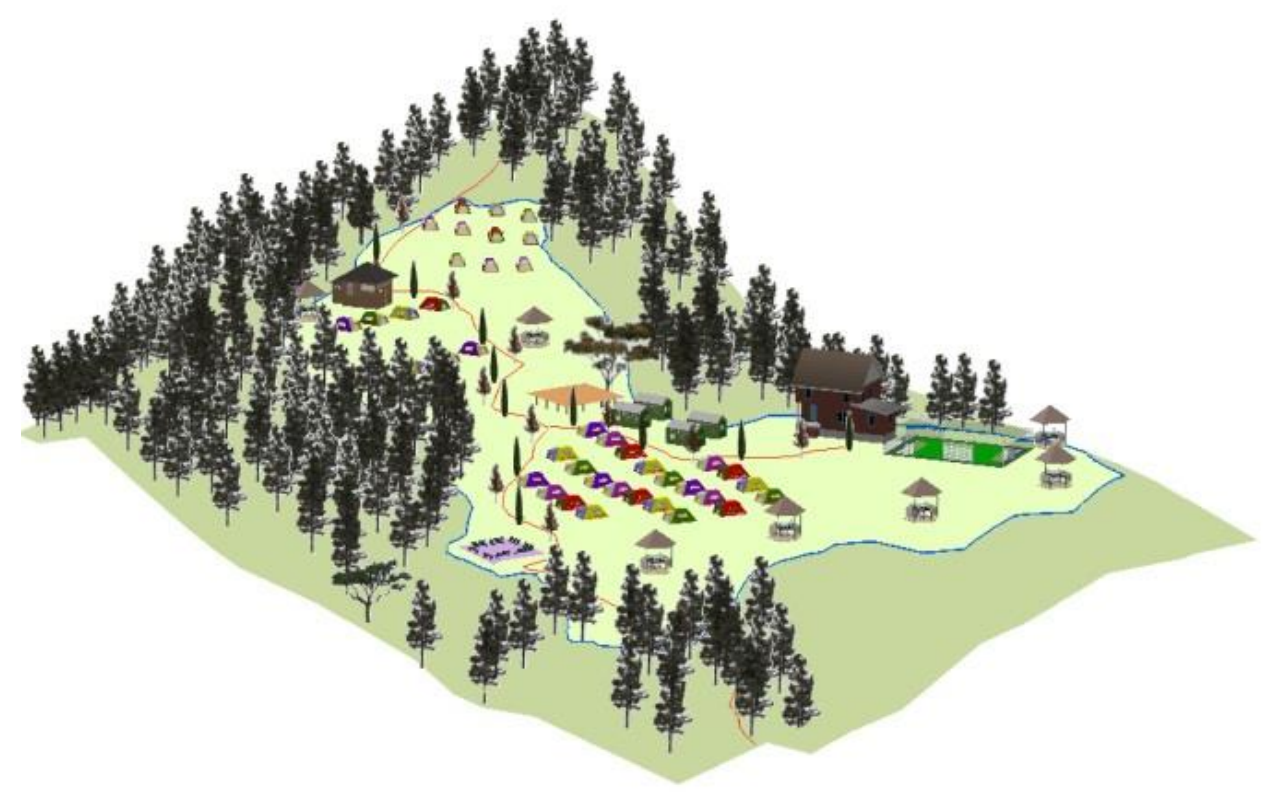

Gambar 6. Peta tiga dimensi rancangan kemah konservasi

\section{Fasilitas Rumah Pengelola dan Pondok Ibadah}

Rumah pengelolah terletak dibagian Timur areal perkemahan dengan dua arah view yang sedikit tertutup dengan pohon-pohonan, sedangkan pondok ibadah terletak di bagian barat dengan view yang terbuka ke arah Timur dimana Gunung Malakka terlihat jelas. Kedua bangunana ini dilengkapi dengan fasilitas MCK, sehingga pekemah blok I dan II menggunakan fasilitas MCk pada pondok ibadah, sedangkan pekemah blok III dan IV menggunakan fasilitas MCK pada rumah pengelola

\section{Fasilitas Air Bersih}


Fasilitas air bersih berupa bak penampungan yang diletakkan pada bagian tertinggi di kaki bukit Bulu Pareppekang. Bak penampungan ini berupa empat unit penampungan berkapasitas 1.250 liter yang saling berhubungan sehingga mempunyai volume penampungan 5000 liter. Sumber air berasal dari mata air pinus yang berjarak $800 \mathrm{~m}$ dari lokasi perkemahan. Dari lokasi penampungan ini, air dialirkan ke pondok pengelola dan rumah ibadah, dimana pada kedua tempat tersebut dilengka[i dengan fasilitas MCK.

\section{Fasilitas Panggung Budaya}

Fasilitas panggung budaya bagian tengah lokasi perkemahan, yang dapat di lihat oleh $75 \%$ tenda tanpa harus berpindah dari tempatnya. Panggung budaya ini akan terlihat dengan baik dari Blok I, II dan IV, sedangkan dari Blok III haya dapat dilihat dengan baik oleh pekema pada baris satu dan dua dari atas.

\section{Fasilitas Resting Area}

Resting area adalah areal datar dengan tutupan beberapa tajuk pohon yang rindang, berukuran kurang lebih $6 \mathrm{~m} \times 6 \mathrm{~m}$. Lokasi ini terletak di depan jurang dengan view ke arah Selatan dimana pemandangan jajaran pegunungan terlihat jelas. Resting area ini dilengkapi dengan kursih panjang dengan posisi berkeliling dengan fasilitas meja besar di bagian tengah. Selain untuk duduk bersantai, resting area digunakan untuk diskusi atau tempat makan bersama sambil menikmati pemandangan alam yang ada dikejauhan

\section{Fasilitas Gazebo}

Beberapa gazebo diletakkan di sekitar blok tenda camping. Masing-masing blok diletakkan gazebo sebagai tempat bersantai. Ada dua Gazebo yang menghadap ke Panggung budaya, satu di bagian timur menghadap ke Puncak Gunung Bulu Dare' yang terletak di bagian utara dari areal perkemahan

\section{Fasilitas Olah Raga}

Ruang terbuka di atas puncak pada bagian Timur areal perkemahan di dekat rumah pengelola, disiapkan sebagai tempat olah raga dan senam, serta kegiatan olah raga lainnya. Karena ukurannya yang mencapai $10 \mathrm{~m} \times 20$ $\mathrm{m}$, maka lapangan ini cocok terutama untuk olah raga Futsal.

\section{Fasilitas Api Unggun}

Fasilitas untuk kegiatan api unggun, berada di bagian tengah sebelah selatan persis berhadapan panggung budaya, tetapi pada ketinggian yang lebih rendah dari panggung budaya tersebut. Fasilitas kegiatan api unggun ini, hampir terlihat dari semua blok kemah. Peta desain tapak kemah konservasi, diperlihatkan pada Gambar 5, sedangkan desain kemah konservasi dalam bentuk tiga dimensi, diperlihatkan pada Gambar 6 .

\section{Rancangan Kegiatan Pendidikan Lapangan Konservasi Sumberda Alam}

\section{Dasar Penyusunan Kegiatan Pendidikan Lapangan}

Kegiatan pendidikan lapangan konservasi sumberdaya alam, adalah bagian dari kegiatan kemah konservasi yang bertujuan untuk memupuk dan menumbuh-kembangkan rasa cinta alam dan konservasi sumberdaya alam hayati dan ekosistemnya dari pengunjung atau pekemah. Selain itu, kagiatan pendidikan lapangan ini juga bertujuan untuk meningkatkatkan rasa kepedulian dan peran serta generasi muda dalam upaya menjaga kualitas, keseimbangan dan peelstarian alam (Direktorat Pemanfaatan Jasa Lingkungan dan Wisata Alam, 2009; Hamiuddin, 2011). Rancangan pembelajaran lapangan, dikaitakan dengan tiga hal pokok, yakni; (1) pengenalan kekayaan alam hayati dan non hayati, (2) Pengenalan proses ekologi, (3) Pengenalan manajemen kawasan konservasi.

Ketiga hal tersebut di atas, diharapkan akan menggugah pengertian pengunjung perkemahan sehingga dapat memahami tentang cara dan manfaat pelaksaan konservasi sumberdaya hayati dan ekosistemnya di Laboratorium Lapangan Konservasi Sumberdaya Hayati dan Ekowisata Hutan Pendidikan Unhas.

\section{Model Pelaksanaan Kegiatan Pendidikan Lapangan}

Untuk mencapai ketiga sasaran pokok dari rancangan pembelajaran konservasi di lapangan, disusun rencana pembelajaran dalam bentuk praktek langsung yang diaplikasikan dalam bentuk jenis permainan dan kunjungan lapangan di sekitar arael perkemahan. Berbagai jenis permainan standar untuk kegiatan kemah konservasi, diadobsi untuk menyesuaikan dengan potensi sumberdaya alam dan ketersediaan fasilitas yang ada di Laboratorium Lapangan, disajikan pada Tabel 2.

\section{PEMBAHASAN}

Desain tapak kemah konservasi di Laboratorium Lapangan Konservasi Sumberdaya Hutan dan Ekowisata telah melengkapi sebagian besar rencana pengelolaan laboratorium Konservasi Sumberdaya Hutan dan Ekowisata. Penggunaan teknologi digital elevation model dalam penelitian ini telah banyak membantu dalam menetapkan kontur detail yang belum tersedia dan sangat dibutuhkan dalam perencanaan lanscap, sehingga menghasilkan desain tapak yang menarik dan mengikuti tata lingkungan atau landscap lokal.

Dengan tersedianya desain tapak ini, kegiatan perkemahan untuk tujuan kegiatan ekowisata dan pendidikan konservasi sumberdaya alam telah bisa 
Tabel 2. Model Pelaksanaan Kegiatan Pendidikan Lapangan

\begin{tabular}{|c|c|c|c|c|}
\hline No. & Pokok Kegiatan & $\begin{array}{c}\text { Metode } \\
\text { Pelaksanan }\end{array}$ & $\begin{array}{c}\text { Lokasi } \\
\text { Pelaksanaan }\end{array}$ & Jenis Kegiatan \\
\hline \multirow[t]{10}{*}{1.} & Pengenalan Kekayaan & Semi & Areal & Paduan senja \\
\hline & Alam Hayati dan Non & Penelitian & Perkemahan & Menyongsong fajar \\
\hline & Hayati & & Stasiun & Pengamatan burung \\
\hline & & & Penelitian & Pengamatan babi hutan di kubangan \\
\hline & & & & Membuat print tapak kaki satwa liar \\
\hline & & & & Pengenalan jenis pohon \\
\hline & & & & Pengamatan reptil malam hari \\
\hline & & Wisata Alam & $\begin{array}{l}\text { Areal } \\
\text { Perkemahan }\end{array}$ & Kunjungan ke Air Terjun Akasia \\
\hline & & & Stasiun & Kunjungan ke Sungai Ganggang \\
\hline & & & Penelitian & Mendaki ke Puncak 88 \\
\hline \multirow[t]{5}{*}{2.} & Pengenalan Proses & Semi & Stasiun & Fungsi lindung \\
\hline & Ekologi & Penelitian & Penelitian & $\begin{array}{l}\text { Rantai dan jaring makanan } \\
\text { Rahasia di lantai hutan }\end{array}$ \\
\hline & & & $\begin{array}{l}\text { Sungai } \\
\text { Mahaka }\end{array}$ & Rahasia kehidupan di sungai \\
\hline & & Pembelajaran & Jalan setapak & Manajemen jalan setapak \\
\hline & & & $\begin{array}{l}\text { Lokasi } \\
\text { perkemahan }\end{array}$ & Manajemen perkemahan \\
\hline \multirow[t]{5}{*}{3.} & Pengelolaan Kawasan & Wisata Alam & Stasiun & Pengenalan zona lindung \\
\hline & Konservasi & & Penelitian & Pengenalan zona wisata \\
\hline & & Pembelajaran & Lab. & Pengelolaan laboratorium lapangan KSDHEW \\
\hline & & & Lapangan & Pembuatan gula merah \\
\hline & & & KSDHEW & Pemandu wisata \\
\hline
\end{tabular}

dilakukan dengan baik berdasarkan prinsip-prinsip ekologi dan konservasi. Ford, (1981) dan Setiono (2011) menjelaskan bahwa pendidikan konservasi merupakan satu usaha sadar yang dilakukan secara berulang-ulang kali atau dengan kata lain secara terus-menerus supaya masyarakat memiliki kesedaran atau kepedulian konservasi terhadap alam sekitarnya dan segala permasalahannya yang memiliki pengetahuan, sikap, keahlian, motivasi dan komitmen untuk ikut memecahkan masalah konservasi. Disinilah latak peranan hasil penelitian yang menyediakan rancangan sarana pendidikan konservasi dalam bentuk camping ground beserta segala fasilitas pendukungnya.

Ketersediaan modul model pendidikan lapangan yang disesuaikan dengan keadaan dan kegiatan penelitian yang selama ini dilakukan di Laboratorium Lapangan Konservasi Sumberdaya Hutan dan Ekowisata akan membantu pengunjung dari berbagai tingkatan umur dan pendidikan dalam memahami sumberdaya alam dan proses ekologi yang bekerja pada ekosistem di Hutan pendidikan Unhas pada umumnya, dan khususnya di Laboratorium Lapangan Konservasi Sumberdaya Hutan dan Ekowisata, sehingga diharapkan mereka akan mendapat pengetahuan dan cara berpikir tentang sumberdaya alam dan upaya konservasi melalui pemanfaatan yang berkelanjutan. Hal ini sejalan dengan Hamiuddin (2011) dan Setiono (2011) yang menyatakan bahwa pendidikan konservasi sebagai pendidikan yang mengharapkan adanya perubahan tingkah laku, sikap dan cara berpikir, terutama yang berkaitan dengan pengelolaan sumber daya alam dan ekosistemnya, yang harus dimulai sejak dini dan dapat dilaksanakan di lingkungan rumah secara non formal maupun di tempat terbuka seperti areal perkemahan.

\section{E. KESIMPULAN}

Desain kemah konservasi di Laboratorium Lapangan Konservasi Sumebrdaya Hutan dan Ekowisata, terdiri dari tiga blok lokasi tenda dom yang berkaoasitas 3 - 4 orang dan satu blok tenda platon yang berkapasitas $10-20$ orang. Total kapasitas tampung sebanyak 39 tenda dom dan empat tenda platon. Areal perkemahan ini direncanakan mempunyai fasilitas penunjang perkemahan berupa panggung budaya, resting area, delapan unit Gazebo, Musallah, Rumah pengelola/ gudang, lokasi api unggun, dan lapangan Futsal, serta memiliki rancangan pendidikan lapangan konservasi sumberdaya hayati, yang dikelompokkan kedalam (1) pengenalan sumberdaya alam, (2) pengenalan proses ekologi dan (3) pengenalan pengeloaan kawasan konservasi.

\section{DAFTAR PUSTAKA}

Achmad, A., N.P. Oka., A. Umar dan Asrianny. (2012a). Pengembangan Ekowisata Di Laboratorium Lapangan Konservasi Sumberdaya Hutan dan Ekowisata. Makassar: Lembaga Penelitian dan Pengabdian Kepada Masyarakat Universitas Hasanuddin. 
Achmad, A., N.P. Oka., A. Umar dan Asrianny. (2012b). Identifikasi Tutupan Vegetasi dan Potensi Fisik Untuk Pengembangan Ekowisata Di Laboratorium Lapangan Konservasi Sumberdaya Hutan dan Ekowisata Hutan Pendidikan Unhas. Jurnal Penelitian Kehutanan Wallacea. 1(2): 87-102. ISSN 2302-299X.

Achmad, A., N. P. Oka, R. I. Maulany and Asrianny. (2015). Sebaran dan Frequensi Kemunculan Burung Elang Sulawesi (Spizaetus (nisaetus) lanceolatus) di Hutan Pendidikan Unhas. Prosiding Seminar Nasional PERTETA di Makassar. Tema: "Peran Perteta Dalam Mendukung Swasembada Pangan 2017"

Dardak, A. H. (2006). Perencanaan Tata Ruang Bervisi Lingkungan Sebagai Upaya Mewujudkan Ruang Yang Nyaman, Produktif, Dan Berkelanjutan. Direktorat Jenderal Penataan Ruang. Yogyakarta: Departemen Pekerjaan Umum.

Direktorat Pemanfaatan Jasa Lingkungan dan Wisata Alam. (2009). Pedoman Kemah Konservai. Bogor: Departeman Kehutanan.

Douglas, R.W. (1982). Forest Recreation. New York: Pergamon Press.

Fandeli, C. dan Muhammad. (2009). Prinsip-Prinsip Dasar Mengkonservasikan Lanskap. Yogyakarta: Gadjah Mada University Press.

Ford, P. M. (1981). Principles and Practices of Outdoor/Envirom mental Education. New York: Wiley. Hammerman.
Gogo, A. (2014). Factor Determining Tourists' Choice of Campsite Accomodation. Wildlife Protected Areas, A Case Study of L.Nakuru National Park Kenya.

Hamiuddin. (2011). Pendidikan Konservasi. Diakses dari http://www.rimbawan.or.id/2011/09/pendidikan-konservasi. html.

Ichwan, M. (2009). Perencanaan Lanskap Bumi Perkemahan Ranca Upas Berdasarkan Pendekatan Daya Dukung Ekologi. Bogor: Skripsi pada Fakultas Pertanian Institut Pertanian Bogor (Tidak Dipublikasikan)

Knudson, D.M. (1983). Outdoor Recreation. New York: Mac Millan Publ Co.

Nurisyah, S dan Q. Pramukamto. (1995). Perencanaan Landscap. Program Studi Arsitektur pertamanan. Jurusan Budidaya Pertanian. Bogor: Institut Pertanian Bogor.

Robin. (2003). Hubungan antara program kemah konservasi dengan pengetahuan dan sikap terhadap lingkungan (studi kasus pada taman nasional Gunung Gede pangrango). Thesis pada Universitas Indonesia, Jakarta. (Tidak Dipublikasikan)

Sulaeman, I. (1983). Petunjuk Praktis Berkemah. Jakarta: Gramedia.

Setiono, D. (2011). Pendidikan Konservasi. Makalah disajikan dalam Pelatihan "Pendidikan Konservasi Alam", Angkatan 26. Diselenggarakan oleh The Indonesian Wildlife Conservation Foundation (IWF) dan Balai Taman Nasional Alas Purwo. Banyuwangi Jawa Timur 